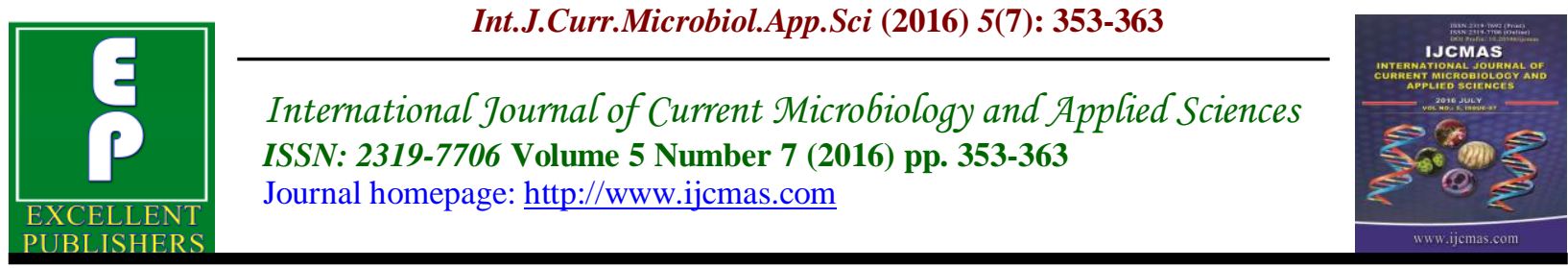

Original Research Article

http://dx.doi.org/10.20546/ijcmas.2016.507.038

\title{
Microbial Flora on Medical Students' White Coat and an Analysis of its Associated Factors: A Cross Sectional Study
}

\author{
Trupti B. Naik ${ }^{1 *}$, Amruthkishan Upadhya ${ }^{2}$, Vijaykumar Mane ${ }^{3}$ and Asmabegaum Biradar ${ }^{4}$ \\ ${ }^{1,2}$ Department of Microbiology, Subbaiah Institute of Medical Sciences, \\ Shivamogga, Karnataka, India \\ ${ }^{3}$ Department of Community Medicine, Koppal Institute of Medical Sciences, \\ Koppal, Karnataka, India \\ ${ }^{4}$ Department of Microbiology, Al-Ameen Medical College, Bijapur, Karnataka, India \\ *Corresponding author
}

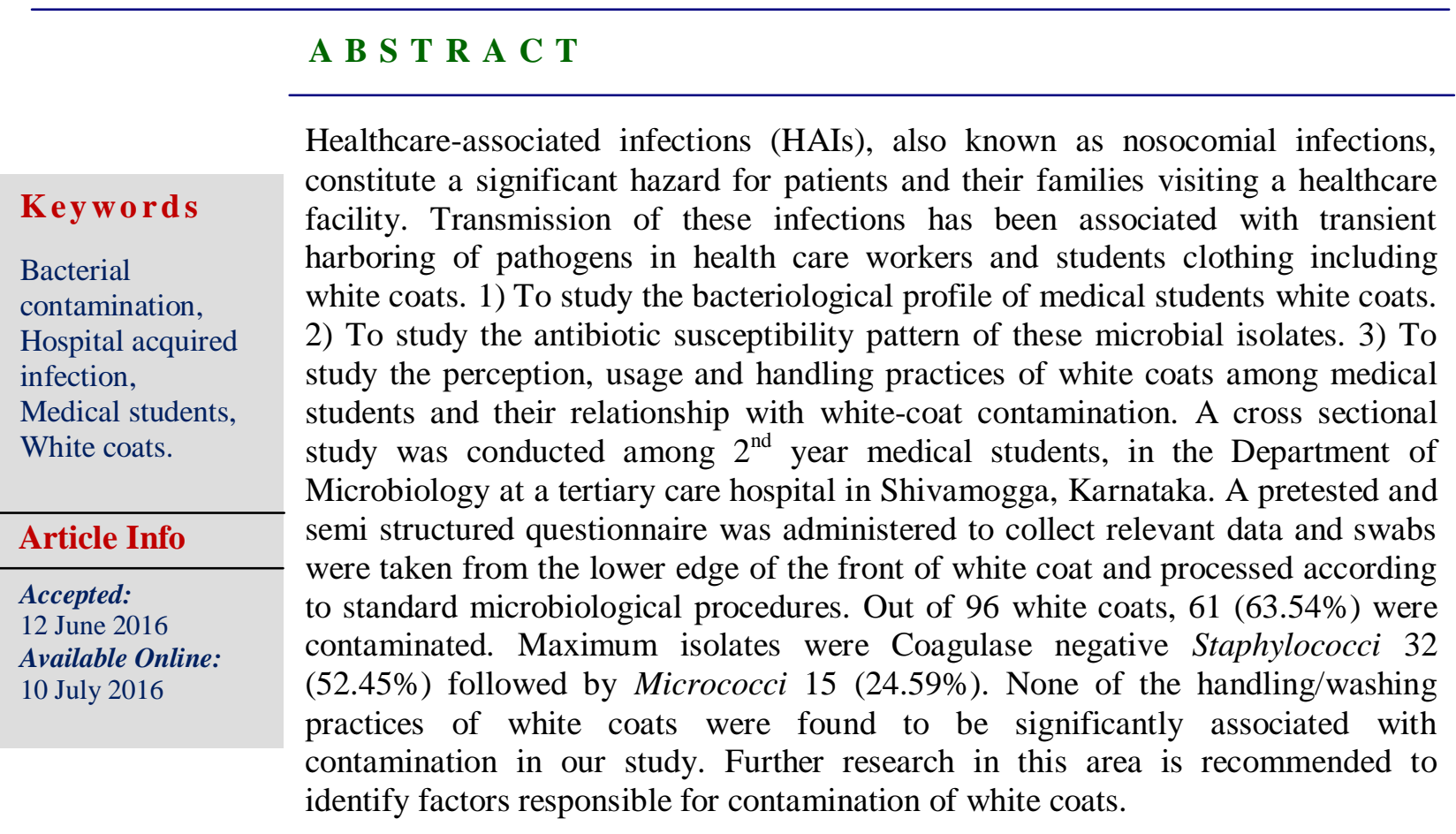

\section{Introduction}

Healthcare-associated infections (HAIs), also known as nosocomial infections, constitute a significant hazard for patients and their families visiting a healthcare facility. The World Health Organization (WHO) defines HAI as an infection occurring in a patient in a Health care facility in whom the infection was not present or was incubating at the time of admission. This includes infections acquired in the hospital but appearing after discharge, and also occupational infections among staff of the facility (Uneke et al., 2010).

HAIs are a major public health problem in both developed and developing countries. 
They cause a severe impact especially in poor resource settings, where the rate of infection is estimated to range from 25 to 40 $\%$. Studies have shown that HAIs exert a tremendous toll on patients, their families and health care systems, resulting in increased morbidity and mortality, and thereby increasing healthcare costs. An estimated 1.4 million people worldwide suffer from infections acquired in hospitals at any point of time (Uneke et al., 2010; Mwamungule et al., 2015).

A white coat, apron or laboratory coat is a knee-length overcoat or smock worn by medical professionals or by those involved in laboratory work to protect their street clothes. It is one of the personal protection equipments (PPE) to prevent contamination of skin and clothing of a health care professional from direct contact with infected saliva, blood, aerosols etc. which are unavoidable in hospital environment (Priya et al., 2009). Wearing white coats is an accepted practice in medical profession, however when, where and how to wear and wash them vary among individuals, their specialties and even between different institutions.

Recently there has been a concern that aprons may play a big role in transmitting infections within and outside hospital settings. Patients-to-patients transmission of infections within health care facilities has been associated with transient harboring of pathogens in health care workers and students clothing including white coats. It is very common to see health care workers and students wearing white coats outside clinical areas such as canteen, supermarkets, library etc. It is also very common to see people hanging them in their cars and offices or carrying them frequently outside hospital premises (Qaday et al., 2015; Saxena et al., 2013; Banu et al., 2012). These contaminated coats may act as fomites for the continued dissemination of bacteria. To make matter worse, HAI have made lethal combination with antibiotic resistance (Treakle, et al., 2000). Potentially pathogenic bacteria (including resistant strains) have been isolated from different sites of aprons of health care workers in different studies and a study by Loh et al. (2000) has found medical student's aprons being contaminated with bacteria, much more heavily than those of residents and attending physicians.

In 2005, WHO Patient Safety Initiative launched the First Global Patient Safety Challenge to galvanize international focus and action on the critical issue of HAIs. As per this initiative, any potential source of HAIs that could threaten the wellbeing of individuals within healthcare facilities should be investigated and mitigated (Mwamungule et al., 2015).

With this background, the following study was planned to find out the level and pattern of microbial contamination present on the aprons of medical students along with their antibiotic susceptibility. Students' way of handling the coat and cleaning as well as their perception towards white coat's contamination was also investigated.

The main objectives of this study were to study the bacteriological profile of medical students white coats along with their antibiotic susceptibility pattern and also to study the perception, usage and handling practices of white coats among medical students and their association with whitecoat contamination.

\section{Materials and Methods}

\section{Study site and design-}

A cross sectional study was conducted in the Department of Microbiology at a tertiary 
care hospital in Shivamogga, Karnataka after obtaining approval from the institutional ethical committee.

\section{Study Population}

96 medical students of $2^{\text {nd }}$ year were included in the study. Those students who were absent on the day of data collection were excluded from the study. The purpose of the study was explained in detail to them and an informed consent was taken. A pretested and semi structured questionnaire was used to collect socio demographic data and information relevant to perception, usage and handling of white coats among them.

\section{Sampling of coats}

Lower edge of front of the white coat was the site chosen to take samples. Sterile saline dipped cotton swabs were used to collect samples and were collected by gently passing them up and down twice over the site.

\section{Culture and Drug Susceptibility testing}

After collection, the swabs were replaced into the sterile test tubes and were immediately streaked onto blood agar and MacConkey agar and the plates were incubated overnight at $37^{\circ} \mathrm{C}$. The colonies obtained were identified by using standard techniques (Collee et al., 1996). Antibiotic sensitivity testing was done by using Kirby Bauer's disc diffusion method as per CLSI guidelines 2015. The following antibiotics were used:

\section{For Gram positive cocci}

Penicillin (10units), Erythromycin $(15 \mu \mathrm{g})$, Clindamycin $(2 \mu \mathrm{g})$, Ciprofloxacin $(5 \mu \mathrm{g})$, Cotrimoxazole $(25 \mu \mathrm{g})$, Chloramphenicol
(30 $\mu \mathrm{g}), \quad$ Gentamicin $(10 \mu \mathrm{g}), \quad$ Linezolid $310 \mu \mathrm{g})$, Vancomycin $(30 \mu \mathrm{g})$, Teicoplanin $(30 \mu \mathrm{g})$, Tetracycline $(30 \mu \mathrm{g})$.

\section{For Gram negative bacilli}

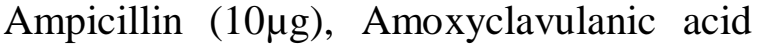
(30 $\mu \mathrm{g})$, Cotrimoxazole (25 $\mu \mathrm{g})$, Tetracycline (30 $\mu \mathrm{g})$, Chloramphenicol (30 $\mu \mathrm{g})$, Gentamicin $(10 \mu \mathrm{g})$, Amikacin $(30 \mu \mathrm{g})$, Ciprofloxacin $(5 \mu \mathrm{g})$, Cefoxitin $(30 \mu \mathrm{g})$, Cefepime (30 $\mu \mathrm{g}), \quad$ Ceftriaxone $(30 \mu \mathrm{g})$, Cephotaxime $(30 \mu \mathrm{g})$, Ceftazidime $(30 \mu \mathrm{g})$, Cefazoline $(30 \mu \mathrm{g})$, Cefuroxime $(30 \mu \mathrm{g})$, Aztreonam $(30 \mu \mathrm{g})$, Piperacillin $(100 \mu \mathrm{g})$, Meropenem $(10 \mu \mathrm{g})$.

\section{Statistical Analysis}

Statistical analysis was done using WHO Epi info 3.5.4 version software. Chi square and $\mathrm{p}$ - value were calculated.

\section{Results and Discussion}

Out of the 96 medical students who participated in the study, $42(43.75 \%)$ were males and $54(56.25 \%)$ were females. Out of 96 white coats screened, majority i.e. 61 $(63.54 \%)$ were found to be contaminated.

The various microbial agents isolated from white coat are shown in Figure no 1. Maximum isolates were Coagulase negative Staphylococci 32 (52.45\%) followed by Micrococci 15 (24.59\%), Gram positive bacilli 9 (14.75\%), Acinetobacter species 4 $(6.55 \%)$ and Staphylococcus aureus 1 $(1.63 \%)$. No case of mixed contamination was observed.

All the Acinetobacter species were sensitive to all the antibiotics. All 33 of the Gram positive cocci were sensitive to Vancomycin, linezolid and chloramphenicol, whereas $20(60.6 \%)$ were 
resistant to penicillin, $13(39.39 \%)$ to erythromycin and clindamycin each, 10 $(31.25 \%)$ to cotrimoxazole and $3(9.09 \%)$ to Cefoxitin as depicted in table no. 1 .

Perception of medical students with regard to white coat contamination is depicted in table no. 2 which shows that $55(57.29 \%)$ considered their white coat to be contaminated. $85(88.54 \%)$ of students believed that their white coats carry germs and $80(83.33 \%)$ believed that white coat can be a potential transmitting agent for pathogens.

White coats from males were slightly more contaminated $(64.28 \%)$ than those of their female counterparts $(62.96 \%)$. However, this difference was not statistically significant ( $\mathrm{p}>0.05)$. Majority i.e. 74 $(77.08 \%)$ of the students in our study were residents of the hostel and the contamination rate was higher i.e. $66.21 \%$ in them than those who resided at home as shown in table no. 3 but it was not statistically significant $(\mathrm{p}>0.05)$.

Table no. 4 depicts the relationship between white-coat usage/handling practices and bacterial contamination of their white coats. $65(67.7 \%)$ students wore the white coat as it was the dress code of the hospital whereas $58(60.41 \%)$ wore them to look professional. $68(70.83 \%)$ said they wear white coat all the time and they had $61.76 \%$ of contamination rate. White coats of students who used them only during hospital duties 4(4.16) had lower bacterial contamination rate when compared with those who used during hospital, college and outside campus 8 (8.33). Only $7(7.29 \%)$ students in our study practiced exchanging white coats among themselves and they had the maximum $(85.71 \%)$ contamination rate. There was no significant difference ( $\mathrm{p}>$ 0.05 ) between contamination rate among those who had spillage on their aprons and those who did not had. There was slightly higher contamination rate among those who usually ate wearing their white coats than those who do not. There was no significant difference $(p>0.05)$ in the contamination levels between those who wear white coats for more than 8 hours $(63.15 \%)$ compared to those who wear for $<8$ hours in a day $(64.1 \%)$. There was slightly higher contamination rate among the white coats that was worn for 6 days and more in a week than those which were worn for less than 6 days. None of the above mentioned factors were significantly associated with contamination of the white coat $(\mathrm{p}>0.05)$.

Table no. 5 depicts medical student's practice of washing white coat and its association with contamination rate. Majority i.e.79 (82.29\%) of students had two white coats and contamination rate was found to be higher among students having three white coats. The degree of contamination was similar irrespective whether the white coat was washed by self or in the laundry. $44(45.83 \%)$ of medical students washed white coat weekly once and they had slightly higher contamination rate i.e. $65.9 \%$. Maximum $65(67.70 \%)$ students washed their white coats within 2 days. Higher $(68.18 \%)$ contamination rate was observed among white coats that were washed from 3-6 days. None of the above mentioned factors were significantly associated with contamination of the white coat $(\mathrm{p}>0.05)$.

From time immemorial, the white coat brings credibility and dignity to the medical profession (Muhadi SA et al., 2007). However, recently white coats have been shown to harbour pathogenic organisms and so these may have a role in the transmission of pathogenic microorganisms (Wong $\mathrm{D}$ et al., 1991). Our study revealed contamination 
rate of $63.54 \%$ in white coats of medical students. Other studies have found whitecoat contamination rate ranging from $23 \%$ to 95\% (Uneke et al., 2010; Mwamungule et al., 2015; Qaday et al., 2015; Treakle et al., 2000; Wong et al., 1991; Pilonetto et al., 2004; Srinivasan et al., 2007).

Coagulase negative Staphylococci were the most commonly isolated organism followed by Micrococci and Gram positive bacilli in our study. This is consistent with the spectrum of bacterial agents isolated in the studies done by Priya et al., (2009); Wong et al., (1991), Pilonetto et al., (2004); Srinivasan et al., (2007); Moravvej et al., (2013) and Pydi et al., (2015). However few other studies have found Staphylococcus aureus as the predominant organism contaminating white coats (Qaday et al., 2015; Saxena et al., 2013; Banu et al., 2012; Treakle et al., 2000; Muhadi et al., 2007). Gram negative bacilli were isolated but these were significantly lesser in number. This is comparable to the finding reported from other studies (Muhadi et al., 2007, Moravvej et al., 2013; Zachary et al. 2001; Grabsch et al. 2006). This difference might be due to differences in the geographical locations of the study. All these microorganisms are frequently found in the hospital environment and are mainly skin commensals, but they have also been implicated as causative agents of nosocomial infections. (Nester et al., 2004; Loh et al., 2000). Coagulase negative staphylococci which are used to be considered as harmless commensals or contaminants, have emerged as major pathogens as medical technology has advanced which cause endocarditis, otitis media and infections of joint prosthesis, vascular grafts, and cardiac pacemakers (Pydi et al., 2015). Thus, students white coat can be a potential source of contamination.

Table.1 Antibiotic susceptibility pattern of Gram positive cocci ( $n=33)$

\begin{tabular}{|l|c|c|c|c|}
\hline \multirow{2}{*}{ Antibiotics } & \multicolumn{2}{|c|}{ Sensitive } & \multicolumn{2}{c|}{ Resistant } \\
\cline { 2 - 5 } & No. & \% & No. & \% \\
\hline Penicillin & 13 & 39.39 & 20 & 60.60 \\
\hline Erythromycin & 20 & 60.60 & 13 & 39.39 \\
\hline Clindamycin & 20 & 60.60 & 13 & 39.39 \\
\hline Tetracycline & 29 & 87.87 & 4 & 12.12 \\
\hline Cefoxitin & 30 & 90.90 & 3 & 9.09 \\
\hline Chloramphenicol & 33 & 100 & 0 & 0 \\
\hline Ciprofloxacin & 27 & 81.81 & 6 & 18.18 \\
\hline Cotrimoxazole & 23 & 69.69 & 10 & 31.25 \\
\hline Gentamicin & 29 & 87.87 & 4 & 12.12 \\
\hline Vancomycin & 33 & 100 & 0 & 0 \\
\hline Linezolid & 33 & 100 & 0 & 0 \\
\hline Teicoplanin & 18 & 54.54 & 15 & 45.45 \\
\hline
\end{tabular}


Table.2 Distribution of study subjects according to their perception towards white coat and its contamination.

\begin{tabular}{|c|c|c|}
\hline & $\begin{array}{l}\text { No. of students } \\
(\mathbf{n}=96)\end{array}$ & $\%$ \\
\hline \multicolumn{3}{|c|}{ Do u perceive your white coat to be clean if it has no stains? } \\
\hline Yes & 21 & 21.87 \\
\hline No & 75 & 78.12 \\
\hline \multicolumn{3}{|c|}{ Do u perceive your white coat to be clean if collar and pockets are clean? } \\
\hline Yes & 20 & 20.83 \\
\hline No & 76 & 82.29 \\
\hline \multicolumn{3}{|c|}{ Do you consider your white coat to be contaminated with or without stains } \\
\hline Yes & 55 & 57.29 \\
\hline No & 41 & 42.7 \\
\hline \multicolumn{3}{|c|}{ Do you think your white coat carries germs? } \\
\hline Yes & 85 & 88.54 \\
\hline No & 11 & 11.45 \\
\hline \multicolumn{3}{|c|}{$\begin{array}{l}\text { Do you believe that the white coat can be a potential transmitting agent for } \\
\text { pathogens? }\end{array}$} \\
\hline Yes & 80 & 83.33 \\
\hline No & 16 & 16.66 \\
\hline
\end{tabular}

Table.3 Distribution of study subjects according to their white-coat usage/handling practices and its association with bacterial contamination of their white coats.

\begin{tabular}{|c|c|c|c|c|c|}
\hline $\begin{array}{c}\text { Basic } \\
\text { variables }\end{array}$ & $\begin{array}{c}\text { No. of students } \\
\text { white coats } \\
\text { examined } \\
\text { n=96 }(\%)\end{array}$ & $\begin{array}{l}\text { No. of white } \\
\text { coats } \\
\text { contaminated }\end{array}$ & $\begin{array}{c}\text { Contaminatio } \\
\text { n rate } \\
(\%)\end{array}$ & $\begin{array}{c}\text { Chi square } \\
(\chi 2) \\
\text { Value }\end{array}$ & $P$ value \\
\hline \multicolumn{6}{|l|}{ Gender } \\
\hline Male & $42(43.75)$ & 27 & 64.28 & \multirow[b]{2}{*}{0.018} & \multirow[b]{2}{*}{0.894} \\
\hline Female & $54(56.25)$ & 34 & 62.96 & & \\
\hline \multicolumn{6}{|l|}{ Residence } \\
\hline Home & $22(22.91)$ & 12 & 54.54 & \multirow[b]{2}{*}{0.997} & \multirow[b]{2}{*}{0.318} \\
\hline Hostel & 74 (77.08) & 49 & 66.21 & & \\
\hline
\end{tabular}


Table.4 Distribution of study subjects according to their white-coat usage/handling practices and its association with bacterial contamination of their white coats.

\begin{tabular}{|c|c|c|c|c|c|}
\hline & $\begin{array}{c}\text { Number of white } \\
\text { coats examined } \\
n=96(\%)\end{array}$ & $\begin{array}{l}\text { No. of white } \\
\text { coats } \\
\text { contaminated }\end{array}$ & $\begin{array}{c}\text { Contamination } \\
\text { rate } \\
(\%) \\
\end{array}$ & $\begin{array}{c}\text { Chi square } \\
(\chi 2) \\
\text { Value } \\
\end{array}$ & $\begin{array}{c}P \\
\text { value }\end{array}$ \\
\hline \multicolumn{6}{|c|}{ The reason to wear white coat $*$} \\
\hline To cover clothing & $8 \quad(8.33)$ & \multirow{5}{*}{-} & \multirow{5}{*}{-} & \multirow{5}{*}{-} & \multirow{5}{*}{-} \\
\hline To appear professional & $58 \quad(60.41)$ & & & & \\
\hline Dress code of hospital & $65(67.7)$ & & & & \\
\hline For usage of pockets & $13(13.54)$ & & & & \\
\hline Any other & $8(8.33)$ & & & & \\
\hline \multicolumn{6}{|c|}{ How do you carry white coat in and around campus } \\
\hline On the hands & $2(2.08)$ & 2 & 100 & \multirow{4}{*}{1.278} & \multirow{4}{*}{0.528} \\
\hline Pack in isolated bag & $0 \quad(0)$ & 0 & 0 & & \\
\hline Carry in bag & $26(27.08)$ & 17 & 65.38 & & \\
\hline Wear it all the time & $68(70.83)$ & 42 & 61.76 & & \\
\hline \multicolumn{6}{|c|}{ Frequency of usage of white coats } \\
\hline Only hospital & $4(4.16)$ & 1 & 25 & \multirow[b]{3}{*}{3.038} & \multirow[b]{3}{*}{0.219} \\
\hline Hospital and college & $84(87.50)$ & 51 & 60.71 & & \\
\hline $\begin{array}{l}\text { Hospital , college and } \\
\text { outside campus }\end{array}$ & $8(8.33)$ & 6 & 75 & & \\
\hline \multicolumn{6}{|c|}{ Practice of exchange of white coat } \\
\hline Yes & $7 \quad(7.29)$ & 6 & 85.71 & \multirow[b]{2}{*}{1.602} & \multirow[b]{2}{*}{0.206} \\
\hline No & $89(92.7)$ & 55 & 61.79 & & \\
\hline \multicolumn{6}{|c|}{ Does your white coat has any spillage on it } \\
\hline Yes & $38(39.58)$ & 24 & 63.15 & \multirow[b]{2}{*}{0.004} & \multirow[b]{2}{*}{0.950} \\
\hline No & $58(60.41)$ & 37 & 63.79 & & \\
\hline \multicolumn{6}{|c|}{ Use of white coat while eating } \\
\hline Yes & $79 \quad(81.25)$ & 51 & 65.38 & \multirow[b]{2}{*}{0.199} & \multirow[b]{2}{*}{0.656} \\
\hline No & $17(17.7)$ & 10 & 58.82 & & \\
\hline \multicolumn{6}{|c|}{ Length of time of white coat in use } \\
\hline$<8$ hours & $39(40.62)$ & 25 & 64.10 & \multirow[b]{2}{*}{0.009} & \multirow[b]{2}{*}{0.925} \\
\hline$>=8$ hours & $57(59.37)$ & 36 & 63.15 & & \\
\hline \multicolumn{6}{|c|}{ How many days you wear white coat in week } \\
\hline$<6$ Days & $18(18.75)$ & 11 & 61.11 & \multirow[b]{2}{*}{0.056} & \multirow[b]{2}{*}{0.812} \\
\hline 6 Days and more & $78(81.25)$ & 50 & 64.10 & & \\
\hline
\end{tabular}


Table.5 Distribution of study subjects according to their white coat washing practices and its association with contamination of their white coats

\begin{tabular}{|c|c|c|c|c|c|}
\hline & $\begin{array}{l}\text { No. of white coats } \\
\text { examined } \\
n=96(\%)\end{array}$ & $\begin{array}{l}\text { No. of white } \\
\text { coats } \\
\text { contaminated }\end{array}$ & $\begin{array}{c}\text { Contamination } \\
\text { rate } \\
(\%) \\
\end{array}$ & $\begin{array}{c}\text { Chi square } \\
(\chi 2) \\
\text { value } \\
\end{array}$ & $P$ value \\
\hline \multicolumn{6}{|c|}{ No. of white coats do u have? } \\
\hline 1 & $8(8.33)$ & 3 & 37.50 & \multirow{3}{*}{2.557} & \multirow{3}{*}{0.278} \\
\hline 2 & $79 \quad(82.29)$ & 52 & 65.82 & & \\
\hline 3 & $9 \quad(9.37)$ & 6 & 66.66 & & \\
\hline \multicolumn{6}{|c|}{ Type of cleaning } \\
\hline Laundry & $10(16.66)$ & 10 & 62.50 & \multirow[b]{2}{*}{0.060} & \multirow[b]{2}{*}{0.806} \\
\hline Self wash & $86(83.33)$ & 51 & 63.75 & & \\
\hline \multicolumn{6}{|c|}{ How often do you wash your white coat? } \\
\hline Weekly once & $44(45.83)$ & 29 & 65.9 & \multirow{3}{*}{0.000} & \multirow{3}{*}{1.00} \\
\hline Weekly twice & $41(42.7)$ & 26 & 63.41 & & \\
\hline Weekly thrice & $11(11.45)$ & 6 & 60 & & \\
\hline \multicolumn{6}{|c|}{ When your white coat was last washed? } \\
\hline 1- 2 days & $65(67.70)$ & 29 & 44.61 & \multirow{3}{*}{0.458} & \multirow{3}{*}{0.795} \\
\hline 3-6 days & $22(22.91)$ & 15 & 68.18 & & \\
\hline 1 week or more & $9(9.37)$ & 5 & 55.55 & & \\
\hline
\end{tabular}

Fig.1 Distribution of organisms isolated from contaminated white coats $(n=61)$

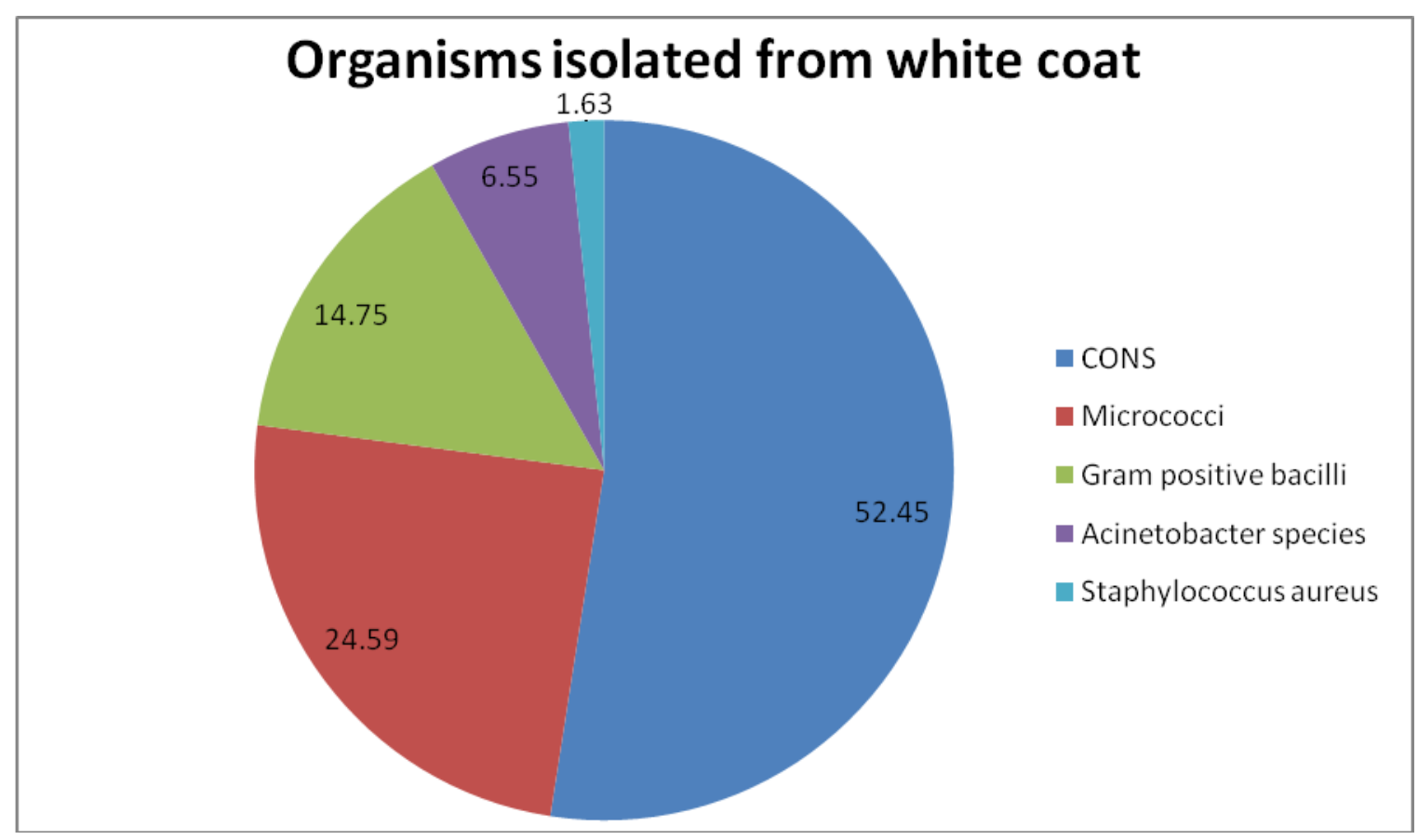


All the Acinetobacter species were sensitive to all the antibiotics tested in our study. All 33 of the Gram positive cocci were sensitive to Vancomycin, linezolid and chloramphenicol, whereas $20 \quad(60.6 \%)$ isolates were resistant to penicillin, 13 (39.39\%) to erythromycin and clindamycin each, $10(31.25 \%)$ to cotrimoxazole, similar to the findings of study done by Priya et al. (2009). The high level of antibiotic resistance exhibited by the bacterial isolates from the coats is of public health significance and has gained importance because they are capable of initiating severe nosocomiasis in a hospital environment and often require contact isolation and aggressive treatment to prevent their spread (Uneke et al., 2010).

More than half of the students considered their white coat to be contaminated in our study. More than $85 \%$ of students knew that their white coats may carry germs and more than $80 \%$ of them believed that the white coat can be a potential transmitting agent for pathogens. Similar finding was observed by Banu et al. (2012) and Muhadi et.al. (2007).

Neither there was significant association between contamination of white coat of medical students with their gender nor with their residential status in our study. Comparable findings were reported by Uneke et al. (2010) and Qaday et al. (2015).

In our study, the handling and washing practices like carrying white coat in and around the campus, frequency of its usage, practice of exchanging among themselves, use of white coats while eating, any spillage on it, length of time in use, number of days per week in use, number of white coats possessed by the students, type of cleaning and the frequency of washing the white coats by the students were not found to be significantly associated with contamination rate of their white coat. Studies done by Qaday et al. (2015) and Treakle et al. (2000) have found no significant association between contamination of white coat with any of the factors similar to the findings of our study.

On the contrary, Uneke, et al., (2010) reported that white coats of physicians who used them only during clinical duties had a significantly lower rate of bacterial contamination compared with those used during both clinical and nonclinical duties. Also study conducted by Wong et al. (1991) found that coats that were more frequently used had significantly greater bacterial contamination than those which were less frequently used. This difference in findings may be due to geographical variation in study location, difference in site of white coat selected for sampling and differences in profile of the study participants.

The level of contamination found on white coats of medical students was very high in our study. Majority of the isolates were Coagulase negative Staphylococci followed by Micrococci and Gram positive bacilli. The level of resistance exhibited by these isolates to various antibiotics used in our study is slightly higher and raises concern.

Perception/ Knowledge of students towards cleanliness of their white coat was good in our study. None of the handling or washing practices by the students was found to be associated with contamination rate of their white coats. Further research is recommended in this area to identify factors responsible for contamination of white coats so that effective steps can be taken to prevent it and thereby to prevent transmission of Hospital acquired infections.

\section{Acknowledgement}

The authors thank the Management of the Subbaiah institute of medical sciences, 
Shivamogga for providing an opportunity to conduct the study. The authors also thank the participants for their cooperation and also the technical personnel in the Microbiology laboratory Mr. Santhosh for the assistance rendered during the study period.

\section{References}

Banu, A., Anand, M., Nagi, N. 2012. White coat as a vehicle for bacterial contamination. J. Clin. Diag. Res., 6(8): 1381-1384.

Clinical and Laboratory Standard Institute. Performance standards for antimicrobial susceptibility testing. 2015. twenty-fifth Informational supplement. CLSI Document M100S25 Wayne, PA. 44-72.

Collee, J.G., Fraser, A.G., Marmion, B.P. and Siminons, A. 1996. Mackie and McCartney Practical Medical Microbiology. $14^{\text {th }}$ ed. New York editors Churchill Livingston.

Grabsch, E.A., Burrell, L.J., O’Keeffe, J.M., Ballard, S. and Grayson, L. 2006. Risk of environmental and healthcare worker contamination with vancomycin resistant enterococci during outpatient procedures and haemodialysis. Infect. Control and Hospital Epidemiol., 27: 287-93.

Loh, W., Ng, V. and Holton, J. 2000. Bacterial flora on the white coats of medical students. J. Hosp. Infect., 45(1): 65-68.

Moravvej, Z., Fakhar, Y., Naderi-Nasab, M. and Askari, E. 2013. Study on bacteria associated with White Coats of healthcare workers in two tertiary hospitals, Mashhad, Iran. J. Med. Bacteriol., 2(3, 4): 17-25.

Muhadi, S.A., Aznamshah, N.A. and Jahanfar, S. 2007. A cross sectional study on the microbial contamination of the medical student's white coats. Malayasian J. Microbiol., 3(1): 35-38. Mwamungule, S., Chimana, H.M., Malama, S., Mainda, G., Kwenda, G. and Muma, J.B. 2015. Contamination of health care workers' coats at the University Teaching Hospital in Lusaka, Zambia: the nosocomial risk. J. Occupational Med. Toxicol., 10(34): 1-6.

Nester, E.W., Anderson, D.G., Roberts, C.E., Pearsall, N.N. and Nester, M.T., 2004. Microbiology: A Human Perspective. 4th Edition. New York. McGraw Hill Companies, Inc.

Pilonetto, M., Rosa, E.A., Brofman, P.R., Baggio, D., Calvário, F,. Schelp, C., Nascimento, A. and Messias-Reason, I. 2004. Hospital gowns as a vehicle for bacterial dissemination in an intensive care unit. Brazilian $J$. Infectious Dis., 8(3): 206-210.

Priya, H,. Acharya, S., Bhat, M. and Ballal, M. 2009. Microbial contamination of the White Coats of Dental staff in the clinical setting. JODDD, 3(4): 136140.

Pydi, S., Pachava, S. and Sanikommu, S. 2015. Microbial contamination of the white coats among preclinical and clinical dental students: A comparative cross-sectional study. J. Indian Assoc. Public Health Dent., 13: 193-6.

Qaday, J., Sariko, M., Mwakyoma, A., Kifaro, E., Mosha, D., Tarimo, R., Nyombi, B. and Shao, E. 2015. Bacterial contamination of Medical doctors and students white coats at Kilimanjaro Christian Medical Centre, Moshi, Tanzania. Int. J. Bacteriol., 15 .

Srinivasan, $\quad$ M., Uma, A., Vinodhkumaradithyaa, A., Gomathi, S., Thirumalaikolundusubramanian. P. 2007. The Medical Overcoat - Is It a Transmitting Agent for Bacterial 
Pathogen?. Japanese Journal of Infectious Diseases 60:121-2.

Saxena RK, Bhosale A, Kazi M, Shirahatti $\mathrm{R}$, Panchwadker D, Diwaney S and Ladkat S, 2013. Microbial flora on aprons of Dental healthcare professionals. J. Dental \& Allied Sci., 2(2): 54-56.

Treakle, A.M., Thom, K.A., Furuno, J.P., Strauss, S.M., Harris, A.D. and Perencevich, E.N. 2009. Bacterial contamination of health care workers' white coats. Am. J. Infect. Control, 37(2): 101-105.

Uneke, C.J. and Ljeoma, P.A. 2010. The potential for nosocomial infection transmission by White Coats used by physicians in Nigeria: implications for improved patient-safety initiatives. World Health and Population, 11(3): 40-54.

Wong, D., Nye, K. and Hollis, P. 1991. The microbial flora on doctor's white coats. British Medical J., 303: 21-28.

Zachary, K.C., Bayne, P.S., Morrison, V.J., Ford, D.S., Silver, L.C. and Hooper, D.C. 2001. Contamination of gowns, gloves, and stethoscopes with vancomycin resistant enterococci. Infect. Control and Hosp. Epidemiol., 22(9): 560-64.

\section{How to cite this article:}

Trupti B. Naik, Amruthkishan Upadhya, Vijaykumar Mane and Asmabegaum Biradar. 2016. Microbial Flora on Medical Students' White Coat and an Analysis of its Associated Factors: A Cross Sectional Study. Int.J.Curr.Microbiol.App.Sci. 5(7): 353-363. doi: http://dx.doi.org/10.20546/ijcmas.2016.507.038 